\title{
DIETARY PHYTOESTROGEN INTAKE AND PREMENOPAUSAL BREAST CANCER RISK IN A GERMAN CASE-CONTROL STUDY
}

\author{
Jakob Linseisen $^{1}{ }^{*}$ Regina PILleR ${ }^{1}$, Silke HeRmann ${ }^{2}$ and Jenny Chang-Claude ${ }^{2}$ \\ ${ }^{1}$ Unit of Human Nutrition and Cancer Prevention, Technical University of Munich, Freising-Weihenstephan, Germany \\ ${ }^{2}$ Department of Clinical Epidemiology, Deutsches Krebsforschungszentrum, Heidelberg, Germany
}

\begin{abstract}
A diet high in isoflavonoids (soy) is associated with lower breast cancer risk in Asian populations. Due to the low soy intake, dietary lignans may be the more important phytoestrogen class in Western populations. We used a population-based case-control study of breast cancer by age 50 in southern Germany to evaluate the association between dietary intake of different phytoestrogens and premenopausal breast cancer risk. Dietary information was collected from 278 premenopausal cases and 666 age-matched controls, using a validated FFQ. Using multivariate logistic regression, the highest vs. lowest intake quartiles of daidzein and genistein yielded significantly reduced ORs $(95 \% \mathrm{CI})$ for breast cancer risk of $0.62(0.40-0.95)$ and $0.47(0.29-0.74)$, respectively. The protective effects of daidzein and genistein were found only for hormone receptor-positive tumors. High intake of other isoflavonoids, e.g., formononetin and biochanin $A$, as well as the sum of isoflavonoids were not associated with a decrease in risk. Breast cancer risk significantly decreased with a high intake of the plant lignan matairesinol (OR $=0.58,95 \%$ CI 0.37-0.94) but not secoisolariciresinol or the sum of plant lignans. However, both estimated mammalian lignans, enterodiol and enterolactone, were inversely associated with breast cancer risk, with ORs $(95 \% \mathrm{CI})$ of 0.6 I (0.39-0.98) and $0.57(0.35-0.92)$, respectively. No effect was found for total phytoestrogen intake. Our results suggest an important role of dietary intake of daidzein and genistein, despite low levels, as well as of matairesinol and mammalian lignans to reduce premenopausal breast cancer risk in this study population.
\end{abstract}

Key words: dietary intake; phytoestrogen; isoflavonoid; plant lignan mammalian lignan; breast cancer; premenopausal women

By definition, phytoestrogens are secondary plant components that show structural similarity to mammalian estrogens and, therefore, are able to bind to mammalian estrogen receptors. ${ }^{1}$ Of the 3 main classes, isoflavonoids, lignans and coumestanes, the isoflavonoids, namely daidzein and genistein, have received the most scientific attention in the last years due to their suggested health effects. ${ }^{2,3}$ Daidzein and genistein are found in high concentrations in soybeans. Consequently, in Asian populations with a fairly high intake of soy and soy products, isoflavonoid intake might be high enough to reveal biologic effects in humans. ${ }^{4}$ Soy consumption has been suggested to contribute to the lower prevalence of breast cancer in Asian compared to Western populations. ${ }^{5,6}$ Since estrogen levels affect breast cancer, ${ }^{7}$ the early postulated anticarcinogenic mechanism is based on the weak estrogen-like activity (compared to endogenous estrogen) of genistein and, to a lesser extent, daidzein, as found in in vitro studies. ${ }^{1,8,9}$ These substances have since been shown to have hormonal receptor-independent anticarcinogenic effects in cancer cell lines and animal studies, such as inhibition of angiogenesis, effects on endogenous hormone concentrations and metabolism as well as antioxidant activity. ${ }^{10-12}$ Stimulatory effects on carcinogenic processes as observed in in vitro studies were not found in vivo. ${ }^{10}$

According to previous reviews, ${ }^{10,13}$ analytic epidemiologic studies in humans support the view of a protective effect of soy consumption or related phytoestrogen intake on breast cancer risk when consumed at an early age (adolescence) or at very high doses. So far, only few investigations have been conducted in populations with low soy intake.
In Western populations with a low intake of isoflavonoids, dietary intake of another class of phytoestrogens, lignans, may be more important. Lignans, mainly secoisolariciresinol and matairesinol, are more widespread in plants and plant products (e.g., whole grains, berries) that are frequently included in the usual Western diet. $^{14,15}$ Analytic data for the lignan content of an acceptable range of foodstuffs have become available only recently, so few studies on the effect of lignan intake on breast cancer risk have been performed. ${ }^{16,17}$ Additionally, lignans undergo bacterial metabolism in the human intestine, and only their metabolites enterodiol and enterolactone are able to pass the intestinal barrier to exert biologic effects. ${ }^{18,19}$ Studies using enterolactone concentrations as biomarkers of lignan intake (and intestinal microbial activity) have given conflicting results: an inverse association with breast cancer risk was found in 3 case-control studies, ${ }^{20-22}$ but no clear answer was given by prospective studies. ${ }^{23,24}$

Therefore, our aim was to assess the association of dietary intake of different phytoestrogens with premenopausal breast cancer risk in a German study population with a Western lifestyle, also considering the hormone receptor status of breast cancer tissue. In addition, the bioavailable intestinal lignan metabolites enterodiol and enterolactone were calculated and related to breast cancer risk.

\section{MATERIAL AND METHODS}

Participants in our population-based case-control study were recruited in the 2 study areas of Freiburg and Rhein-NeckarOdenwald between January 1992 and December 1995. All German-speaking women who were not older than 50 years at the time of diagnosis of incident in situ or invasive breast cancer were eligible. Patients were identified by frequent monitoring of hospital admissions, surgery schedules and pathology records of 38 hospitals. Among the 1,020 eligible patients in both study regions, 706 $(70.2 \%)$ completed the study questionnaire. Controls matched by exact age and study region were selected from a random list of residents derived from the population registries. Of the 2,257 eligible controls, $1,381(61.2 \%)$ participated in the study. ${ }^{25,26}$ The

Abbreviations: BMI, body mass index; CI, confidence interval; EPIC, European Prospective Investigation into Cancer and Nutrition; FFQ, foodfrequency questionnaire; FSH, follicle-stimulating hormone; $\mathrm{LH}$, luteinizing hormone; OR, odds ratio; SHBG, sex hormone-binding globulin.

Grant sponsor: Kurt-Eberhard-Bode-Stiftung; Grant sponsor: Deutsche Krebshilfe; Grant number: 70492.

*Correspondence to: Unit of Human Nutrition and Cancer Prevention, Technical University of Munich, Alte Akademie 16, 85350 FreisingWeihenstephan, Germany. Fax: +49-8161-713931. E-mail: j.linseisen@wzw.tum.de 
study was approved by the local ethical committee, and all participants gave informed consent.

Both cases and controls filled in a self-administered risk factor questionnaire, collecting information on demographic factors, anthropometric measures, menstrual history, reproductive history, breast-feeding history, family history of cancer, smoking history and alcohol consumption. If not otherwise specified, all information was truncated at the reference date, which was the date of diagnosis for cases and the date of questionnaire completion for controls. Menopausal status was assigned according to the reported state half a year before the reference date. The menopausal status of women with previous hysterectomy not accompanied by bilateral oophorectomy was not identifiable and classified as unknown Information on hormone receptor status (estrogen, progesterone) of breast cancer tissue was obtained from pathology reports.

In addition, participants from Rhein-Neckar-Odenwald were asked to complete a self-administered FFQ, recording nutritional habits in the year prior to the diagnosis of breast cancer (cases) or questionnaire completion (controls). The FFQ, consisting of 176 food items, is comparable to the FFQ used for the German part of the EPIC study; it was validated for food group, energy and nutrient intake. ${ }^{27,28} \mathrm{~A}$ detailed description of this FFQ, including the treatment of missing values, was published previously. ${ }^{29}$ The FFQ was returned by 1,288 of the 1,451 participants from RheinNeckar-Odenwald $(88.8 \%)$. The median time between diagnosis and FFQ administration was 209 days for patients. Patients who filled in the FFQ more than 2 years after diagnosis were excluded from analysis. Information about portion size and frequency of consumption for single food items was used to calculate mean food intake per day. Nutrient intake was computed by means of the German food composition table BLS II.3 (Bundesinstitut für gesŭndheitlichen Verbraucherschütz und Veterinärmedizin, Berlin, Germany). Food items were classified into 14 groups. ${ }^{29}$ After exclusion of the top and bottom $1 \%$ of the energy intake range (extreme over- and underreporting), 355 cases and 838 controls were finally included in the analyses.

To estimate dietary phytoestrogen intake, a database of phytoestrogen-containing foods was established using the available analytic data from the literature, focusing on foodstuffs usually consumed in Europe. ${ }^{2,14,30-40}$ The food content of the isoflavonoids (daidzein, genistein, formononetin, biochanin A), coumestanes (coumestrol) and lignans (secoisolariciresinol, matairesinol) was included as aglycons in micrograms per $100 \mathrm{~g}$ edible food portion. If more than one value for the same foodstuff was available, mean values were calculated. Additionally, in vitro data on the intestinal production of enterodiol and enterolactone after incubation with human feces were used to estimate the bioavailable intestinal lignan metabolites per $100 \mathrm{~g}$ of food ingested. ${ }^{41}$ When a particular phytoestrogen was found "in trace amounts" in a certain food, it was assigned to $0.01 \mu \mathrm{g} / 100 \mathrm{~g}$ food. After calculation of the phytoestrogen content of each FFQ item, mean daily intake of the different phytoestrogens was computed for each subject.

The association between phytoestrogen intake and risk of premenopausal breast cancer was estimated by means of conditional logistic regression modeling. ORs and their corresponding 95\% CIs were calculated using the PHREG procedure of the SAS statistical software package, version 8.2 (SAS Institute, Cary, NC) with stratification for exact age. Higher quartiles of phytoestrogen consumption were compared to the lowest quartile of consumption, whereby the distribution of the phytoestrogen intake in controls was used for quartile definition. Results were adjusted for first-degree family history of breast cancer (no, yes), number of births ( 3 categories of 0,1 or $2, \geq 3$ ), duration of breast-feeding ( 4 categories of $0,1-6,7-12,>12$ months), energy intake (deciles), BMI [classified as underweight $\left(<18.5 \mathrm{~kg} / \mathrm{m}^{2}\right)$, normal weight $\left(18.5-30 \mathrm{~kg} / \mathrm{m}^{2}\right)$ and obese $\left.\left(\geq 30 \mathrm{~kg} / \mathrm{m}^{2}\right)\right]$, education level (low, middle, high) and alcohol consumption (3 categories of $0,1-18$ and $>18 \mathrm{~g}$ ethanol/day). Age at menarche, smoking, sports activity and total physical activity did not affect the estimates significantly and, thus, were not used for adjustment. For trend estimation, categorized variables were entered into the regression models as ordinal variables.

\section{RESULTS}

A total of 278 cases and 666 controls were classified as premenopausal at the time of diagnosis (cases) or recruitment (controls) and were, therefore, included in the evaluation. A description of sociodemographic variables and known risk factors for breast cancer is given in Table I. The mean age for cases and controls was 42.6 years ( $\mathrm{SD} \pm 5.48, \pm 5.77$, respectively). Total daily energy intake was significantly different between cases and controls (Table II).

Median dietary intake of phytoestrogens in cases and controls is given in Table II. The higher intake of genistein among controls compared to cases was statistically significant. Additionally, cases and controls differed significantly in formononetin intake. For all other phytoestrogens, no significant differences existed. Secoisolariciresinol contributed nearly $50 \%$ of total phytoestrogen intake of about $1,000 \mu \mathrm{g} /$ day. Relevant food sources for different phytoestrogens are listed in Table III.

Except for genistein (4th vs. 1st quartile), formononetin and biochanin A (3rd vs. 1st quartile), none of the crude estimates for breast cancer risk was statistically significant (Table IV). After adjustment for several risk factors for breast cancer and possible confounders, high intake of daidzein and genistein was inversely associated with premenopausal breast cancer risk (Table IV). For the sum of daidzein and genistein, the risk estimates for both the 3rd and 4th intake quartiles were significantly decreased compared to the lowest intake category, with ORs $(95 \% \mathrm{CI})$ of $0.63(0.41-$ $0.96)$ and $0.56(0.36-0.87)$, respectively $\left(p_{\text {trend }}=0.005\right)$. Intake of formononetin and biochanin A was associated with increased breast cancer risk in the 3rd intake quartile but not the 4th quartile; overall, no significant effect was found for the sum of isoflavonoids (Table IV). Coumestrol intake was also not associated with breast cancer risk.

Of the lignans, no effect was found for secoisolariciresinol. However, premenopausal breast cancer risk decreased with increasing intake of matairesinol $(\mathrm{OR}=0.58,95 \%$ CI $0.37-0.94$ in 4 th $v s$. 1 st intake quartile, $p_{\text {trend }}=0.025$ ). Total intake of plantderived phytoestrogens did not affect breast cancer risk. A high estimated amount of mammalian lignans, enterodiol and enterolactone, was inversely associated with breast cancer risk. ORs $(95 \%$ CIs) for the highest $v s$. lowest quartile were $0.61(0.39-0.98$, $\left.p_{\text {trend }}=0.034\right)$ for enterodiol and $0.57\left(0.35-0.92, p_{\text {trend }}=0.008\right)$ for enterolactone.

If considering only patients who completed the FFQ within 1 year after diagnosis $(n=213)$, adjusted relative risks were only slightly modified with few exceptions: relative risk estimates for the 3rd quartiles of daidzein intake and total isoflavonoid intake became significant, while for matairesinol, enterodiol and enterolactone the point estimates for the 4th intake quartiles slightly increased, with ORs of $0.64,0.66$ and 0.63 , but were no longer statistically significant.

We also examined the combined effect of daidzein and genistein intake and intestinal lignan metabolites. Women were grouped by low (1st and 2nd quartiles) and high (3rd and 4th quartiles) consumption of daidzein and genistein and of enterodiol and enterolactone. High consumption of both phytoestrogen classes showed the strongest risk reduction, with an adjusted OR $(95 \% \mathrm{CI})$ of $0.57(0.36-0.83)$ compared to low consumption of both groups (Table V).

Further, we examined whether the phytoestrogen effect differed by hormone receptor status. Differentiated by estrogen and progesterone receptor status of breast tissue, a significant inverse association between daidzein and genistein intake and breast cancer risk was found only for breast tumors positive for estrogen or 


\begin{tabular}{|c|c|c|c|c|}
\hline & \multicolumn{2}{|c|}{ Cases } & \multicolumn{2}{|c|}{ Controls } \\
\hline & Number & $\%$ & Number & $\%$ \\
\hline \multicolumn{5}{|c|}{$\begin{array}{l}\text { Age at diagnosis/recruitment } \\
\text { (years) }\end{array}$} \\
\hline $24-29$ & 10 & 3.6 & 26 & 3.9 \\
\hline $30-34$ & 25 & 9.0 & 62 & 9.3 \\
\hline $35-39$ & 50 & 18.0 & 123 & 18.5 \\
\hline $40-44$ & 94 & 33.8 & 220 & 33.0 \\
\hline $45-49$ & 85 & 30.6 & 206 & 30.9 \\
\hline $50-52$ & 14 & 5.0 & 29 & 4.4 \\
\hline \multicolumn{5}{|l|}{ BMI $\left(\mathrm{kg} / \mathrm{m}^{2}\right)$} \\
\hline$<18.5$ & 8 & 2.9 & 15 & 2.3 \\
\hline 18.5 to $<30$ & 241 & 87.0 & 609 & 91.4 \\
\hline$\geq 30$ & 28 & 10.1 & 42 & 6.3 \\
\hline \multicolumn{5}{|c|}{$\begin{array}{l}\text { First-degree family history of } \\
\text { breast cancer }\end{array}$} \\
\hline No & 250 & 89.9 & 641 & 96.2 \\
\hline Yes & 28 & 10.1 & 25 & 3.8 \\
\hline \multicolumn{5}{|c|}{$\begin{array}{l}\text { Hormonal receptor status of } \\
\text { tumor }\end{array}$} \\
\hline \multicolumn{5}{|c|}{ Estrogen receptor } \\
\hline Positive & 139 & 62.6 & - & - \\
\hline Negative & 83 & 37.4 & - & - \\
\hline \multicolumn{5}{|c|}{ Progesteron receptor } \\
\hline Positive & 122 & 56.0 & - & - \\
\hline Negative & 96 & 44.0 & - & - \\
\hline \multicolumn{5}{|c|}{ Age at menarche (years) } \\
\hline$<13$ & 108 & 39.0 & 250 & 37.6 \\
\hline $13-14$ & 131 & 47.3 & 323 & 48.6 \\
\hline$>14$ & 38 & 13.7 & 92 & 13.8 \\
\hline \multicolumn{5}{|l|}{ Number of births } \\
\hline 0 & 70 & 25.2 & 158 & 23.7 \\
\hline 1 or 2 & 190 & 68.3 & 417 & 62.6 \\
\hline$>2$ & 18 & 6.5 & 91 & 13.7 \\
\hline \multicolumn{5}{|c|}{$\begin{array}{l}\text { Duration of breast-feeding } \\
\text { (months) }\end{array}$} \\
\hline 0 & 128 & 46.0 & 295 & 44.3 \\
\hline $1-6$ & 102 & 36.7 & 219 & 32.9 \\
\hline $7-12$ & 29 & 10.4 & 92 & 13.8 \\
\hline $13+$ & 19 & 6.8 & 60 & 9.0 \\
\hline \multicolumn{5}{|l|}{ Educational level } \\
\hline Low & 31 & 11.2 & 65 & 9.8 \\
\hline Middle & 178 & 64.0 & 396 & 59.5 \\
\hline High & 69 & 24.8 & 205 & 30.8 \\
\hline \multicolumn{5}{|l|}{ Smoking } \\
\hline Never & 128 & 46.0 & 308 & 46.2 \\
\hline $\mathrm{Ex}$ & 61 & 21.9 & 164 & 24.6 \\
\hline Current & 89 & 32.0 & 194 & 29.1 \\
\hline \multicolumn{5}{|c|}{ Alcohol consumption (g/day) } \\
\hline 0 & 52 & 18.7 & 101 & 15.2 \\
\hline $1-18$ & 191 & 68.7 & 500 & 75.1 \\
\hline & 35 & 12.6 & 65 & 9.8 \\
\hline \multicolumn{5}{|c|}{$\begin{array}{l}\text { Physical activity (MET } \cdot \mathrm{hr} / \\
\text { week }^{1}\end{array}$} \\
\hline$<83.15$ & 78 & 41.7 & 191 & 36.4 \\
\hline $83.15-132.42$ & 59 & 31.6 & 178 & 33.9 \\
\hline$>132.42$ & 50 & 26.7 & 156 & 29.7 \\
\hline
\end{tabular}

${ }^{1}$ MET, metabolic equivalents; data available for 187 cases and 525 controls.

progesterone receptor (Table VI). The effects of enterodiol and enterolactone were independent of hormone receptor status (data not shown)

\section{DISCUSSION}

We found a protective effect of a high intake of genistein and daidzein (isoflavonoids) and matairesinol (lignan) on breast cancer risk. The effect of genistein and daidzein was limited to hormone receptor-positive breast tumors. Additionally, a high amount of estimated enterodiol and enterolactone (mammalian lignans) is inversely related to premenopausal breast cancer risk.
The observed effects of genistein and daidzein were largely unexpected because the intake levels for these compounds are very low (150-160 $\mu \mathrm{g} /$ day) compared to Asian populations (10-30 $\mathrm{mg}$ /day). ${ }^{4}$ Concentrations necessary to reveal hormone receptormediated effects as determined in in vitro studies are unlikely to be reached by the estimated dietary intake range in this study population. This suggests a hormone receptor-independent mechanism of action of these isoflavonoids, which, however, appears to be contradicted by the clear results showing that the genistein and daidzein effects are restricted to hormone receptor-positive tumors. Isoflavonoid effects on hormonal status and hormone metabolism may help explain the findings. Besides in vitro results, human intervention studies in premenopausal women and in men have found a decrease in plasma $17 \beta$-estradiol, progesterone, FSH and LH and an increase in plasma SHBG concentrations after administration of soy (isoflavonoids) or flaxseed (lignans). ${ }^{11,19,42-44}$ In addition, some studies have also shown increased ratios of urinary $2-(\mathrm{OH})$ to $16 \alpha-(\mathrm{OH})$ and $2-(\mathrm{OH})$ to $4-(\mathrm{OH})$ estrogens associated with soy intake. ${ }^{11}$ The latter finding suggests reduced formation of genotoxic and potentially carcinogenic estrogen metabolites. Several enzymes involved in estrogen metabolism can be affected (mainly inhibited) by phytoestrogens, including aromatase and sulfotransferases. ${ }^{12}$ The effects were less pronounced in postmenopausal women. ${ }^{45}$ Thus, our present findings are compatible with the biologic mechanisms showing an important role for isoflavonoids in protecting against hormone-dependent breast cancer through their effects on the generation, transport and removal of endogenous steroid hormones; furthermore, some of these actions are mediated by hormonal receptors and therefore dependent on receptor status. Surprisingly, intake of formononetin and biochanin $\mathrm{A}$ as precursors of daidzein and genistein was unrelated to breast cancer risk or even increased risk (3rd quartile, Table IV). This may indicate very limited conversion of these precursors to their biologically active products.

In contrast to daidzein and genistein, the protective effect found for enterodiol and enterolactone was not modified by hormone receptor status. This implies that there may be differences between the 2 classes of phytoestrogens regarding the biologic mechanisms involved in reducing breast cancer risk. Isoflavonoids and mammalian lignans show similar effects, such as competition with estrogen for binding to estrogen receptors (type II), induction of SHBG, inhibition of some steroid-metabolizing enzymes (aromatase) and antioxidant activity. ${ }^{1,18}$ However, depending on the test systems used, differences between phytoestrogenic compounds have been reported. The possible underlying mechanism for the observed difference warrants investigation.

Two reviews dealing with the health effects of phytoestrogens concluded that protective effects on breast cancer risk might be found in women who consume soy phytoestrogens at an early age (adolescence) or at very high doses. ${ }^{10,13}$ Most of the included studies evaluated the relationship between intake of soy/soy products and disease risk, predominantly in Asian populations. Studies which assessed isoflavonoid or lignan metabolite concentrations in plasma or urine samples in relation to breast cancer yielded inconsistent results. While 2 prospective studies failed to find a significant inverse association between high urinary isoflavonoid excretion or serum enterolactone concentrations and breast cancer risk, ${ }^{23,24} 5$ case-control studies reported a protective effect on breast cancer risk. ${ }^{20-22,46,47}$

Two studies in Asian populations, living in Japan (prospective study) ${ }^{48}$ and the United States (case-control study), ${ }^{49}$ that assessed overall isoflavonoid intake reported an inverse association with breast cancer risk. The effect of dietary intake of isoflavonoids and lignans on breast cancer risk has been assessed only recently in 2 studies in the United States but not yet in Europe. ${ }^{16,17}$ Both US studies, one with a prospective design, ${ }^{17}$ failed to find a significant association with breast cancer or an effect modification by menopausal status or hormone receptor status of the tumor. 
TABLE II - DIETARY INTAKE (MEDIAN, 25\%-75\% PERCENTILE) OF SELECTED PHYTOESTROGENS AND ENERGY IN PREMENOPAUSAL BREAST CANCER CASES $(N=278)$ AND POPULATION-BASED CONTROLS $(N=666)$

\begin{tabular}{|c|c|c|c|c|c|}
\hline & \multicolumn{2}{|c|}{ Cases } & \multicolumn{2}{|c|}{ Controls } & \multirow{2}{*}{$p^{2}$} \\
\hline & Median & $25 \%-75 \%$ Percentile & Median & $25 \%-75 \%$ Percentile & \\
\hline Formononetin & 89.5 & $47.6-156.2$ & 76.9 & $42.1-149.6$ & 0.034 \\
\hline Biochanin A & 12.5 & $7.1-19.2$ & 10.9 & $6.3-19.7$ & 0.174 \\
\hline Daidzein & 109.3 & $50.8-189.6$ & 112.9 & $60.2-192.6$ & 0.434 \\
\hline Genistein & 44.2 & $28.2-69.6$ & 48.1 & $30.6-81.0$ & 0.022 \\
\hline$\Sigma$ Daidzein + genistein & 159.1 & $90.3-249.0$ & 172.1 & $101.4-269.9$ & 0.138 \\
\hline$\Sigma$ Isoflavonoids & 278.9 & $176.5-441.1$ & 289.2 & $173.7-414.7$ & 0.992 \\
\hline Secoisolariciresinol & 530.9 & $275.2-1,409.1$ & 529.0 & $274.2-1,279.8$ & 0.844 \\
\hline Matairesinol & 28.1 & $19.5-37.6$ & 28.5 & $20.0-38.6$ & 0.500 \\
\hline$\sum$ Lignans & 570.3 & $302.5-1,428.2$ & 563.1 & $298.4-1,330.6$ & 0.851 \\
\hline Coumestrol & 15.4 & $7.6-26.0$ & 14.6 & $7.1-26.0$ & 0.753 \\
\hline$\Sigma$ Phytoestrogens & 946.3 & $571.3-1,768.5$ & 962.9 & $588.8-1,760.9$ & 0.902 \\
\hline Enterodiol & 363.1 & $235.2-554.9$ & 376.0 & $241.6-581.7$ & 0.815 \\
\hline Enterolactone & 316.3 & $226.9-445.7$ & 330.8 & $226.5-453.4$ & 0.731 \\
\hline$\Sigma$ Intestinal lignan metabolites & 726.1 & $470.4-1,109.8$ & 752.1 & $483.3-1,163.5$ & 0.815 \\
\hline Energy & 2,245 & $1,738-2,940$ & 2,093 & $1,685-2,646$ & 0.009 \\
\hline
\end{tabular}

${ }^{1}$ Units are $\mu \mathrm{g} /$ day except for "Energy", kcal/day.- ${ }^{2}$ Mann-Whitney $U$-test.

TABLE III - CONTRIBUTION OF FOOD GROUPS AND SUBGROUPS TO THE DIETARY INTAKE OF SELECTED PHYTOESTROGENS IN PREMENOPAUSAL

\begin{tabular}{|c|c|c|c|c|c|c|}
\hline & Daidzein & Genistein & Secoisolariciresinol & Matairesinol & Enterodiol & Enterolactone \\
\hline Potatoes & $0.4 / 0.4$ & $2.3 / 1.8$ & $0.2 / 0.1$ & $4.3 / 3.7$ & $10.4 / 9.4$ & $8.8 / 8.0$ \\
\hline Leafy vegetables & -1 & - & $0.3 / 0.3$ & $7.9 / 7.8$ & - & - \\
\hline Fruiting vegetables & - & $1.1 / 1.0$ & $0.6 / 0.8$ & $0.9 / 0.9$ & $1.4 / 1.4$ & $2.4 / 2.4$ \\
\hline Root vegetables & $0.1 / 0.1$ & $0.2 / 0.2$ & $0.3 / 0.3$ & $0.1 / 0.1$ & $3.3 / 3.3$ & $10.3 / 10.8$ \\
\hline Cabbages & $0.4 / 0.5$ & $0.2 / 0.2$ & $0.4 / 0.4$ & $5.1 / 5.1$ & $2.6 / 2.7$ & $4.8 / 5.1$ \\
\hline Onion/garlic & - & $0.1 / 0.1$ & $2.5 / 2.4$ & $11.2 / 11.0$ & $19.1 / 19.6$ & $5.9 / 6.1$ \\
\hline Sprouts, stalk vegetables & $23.9 / 25.5$ & $45.3 / 42.5$ & $2.8 / 2.5$ & $3.2 / 3.5$ & $16.8 / 14.6$ & $12.2 / 10.7$ \\
\hline Mixed salad/vegetables & $1.3 / 1.6$ & $0.8 / 0.7$ & $0.2 / 0.2$ & $0.1 / 0.1$ & $1.1 / 1.3$ & $2.5 / 3.0$ \\
\hline Legumes & $5.5 / 5.1$ & $11.2 / 9.5$ & $0.1 / 0.1$ & $0.5 / 0.5$ & $1.6 / 1.7$ & $2.5 / 2.5$ \\
\hline Fruits & $0.3 / 0.3$ & $2.4 / 2.0$ & $4.0 / 3.8$ & $2.1 / 2.0$ & $8.7 / 8.2$ & $25.0 / 23.0$ \\
\hline Nuts and seeds & $0.3 / 0.3$ & $1.1 / 0.8$ & $73.0 / 74.7$ & $5.1 / 5.3$ & $28.1 / 30.3$ & $7.7 / 8.3$ \\
\hline Cereals, products of (without bread) & $1.4 / 1.6$ & $2.5 / 3.1$ & $0.4 / 0.4$ & $0.4 / 0.4$ & $0.8 / 0.8$ & $1.6 / 1.7$ \\
\hline Bread & $1.5 / 1.5$ & $3.5 / 2.9$ & $1.3 / 1.3$ & $40.4 / 39.9$ & $5.5 / 6.0$ & $15.4 / 17.2$ \\
\hline Eggs & $3.0 / 3.1$ & - & - & - & - & - \\
\hline Wine & - & - & $3.5 / 3.3$ & $11.2 / 10.7$ & - & - \\
\hline Soy products & $4.3 / 8.2$ & $14.9 / 24.1$ & - & - & - & - \\
\hline Coffee & $52.1 / 46.5$ & $4.2 / 3.2$ & $7.7 / 6.5$ & - & - & - \\
\hline Tea & - & $0.1 / 0.1$ & $2.2 / 2.3$ & $7.1 / 7.5$ & - & - \\
\hline Sauces & $4.4 / 4.6$ & $5.9 / 5.2$ & - & - & - & - \\
\hline
\end{tabular}

${ }^{1}$ Contribution $<0.1 \%$.

For the calculation of individual phytoestrogen intake, analytic data from the literature were used, as described by other groups. ${ }^{15,38,50,51}$ With the exception of daidzein, the dietary intake estimates for the different phytoestrogenic compounds in our subjects are compatible with the results from a Dutch study in women 49-70 years old participating in the Utrecht EPIC cohort. ${ }^{15}$ Data on isoflavonoid intake in 4 European countries (Ireland, Italy, the Netherlands, UK) also estimated an average intake of $<1 \mathrm{mg} /$ day, which was somewhat higher than that found in Germany. ${ }^{52}$ Studies from central Europe reporting lignan intake data are not available. Finnish data regarding dietary lignan intake vary widely but show distinctly lower secoisolariciresinol intake levels than we found here. ${ }^{50,53}$ Reported lignan and coumestrol intake values from 1 of 3 studies in the United States are similar to our results, ${ }^{51}$ while others are not; ${ }^{16,17}$ however, isoflavonoid intake was higher in the United States than in Germany.

Differences in phytoestrogen intake between studies can be explained by differing dietary habits but may also be affected by differences in the phytoestrogen content of food (e.g., soy protein as an ingredient) or differences in the ability of the FFQ employed to assess relevant food items for phytoestrogen intake. As shown in Table III, the important ( $>5 \%$ contribution) sources of daidzein and genistein in the diet of our study population were soy sprouts, legumes, soy products, sauces and coffee (daidzein). Secoisolariciresinol is predominantly provided by nuts and seeds (flaxseeds, pumpkin seeds) and coffee. Potatoes, leafy vegetables, cabbages, onion/garlic, nuts/seeds, wine, tea and especially bread contributed to the total matairesinol intake. The proportional contribution of food groups to the mammalian lignans is spread over a broad variety of foods like different kinds of vegetable, potatoes, fruits, nuts/seeds and bread, indicating differences in lignan sources.

There are 2 major concerns over possible biases that may have affected the results. First, a case-control study design of nutritional studies may suffer from recall bias in cases. This cannot be excluded for the present study. However, limited modification of the diet over time has been indicated, also after a diagnosis of cancer. The type of food consumed can be regarded as a personal dietary preference, so intake levels of most persons are likely to be relatively stable over time. ${ }^{54}$ Zheng et al. ${ }^{47}$ observed that $>90 \%$ of cases reported no appreciable dietary change during the time period from initial cancer diagnosis to urine collection. Additionally, results from EPIC-Heidelberg, obtained with the same nutritional assessment tool, were comparable to the present results in terms of energy and nutrient intake ranges ${ }^{55}$ and, therefore, give some reassurance for the validity of the data. Further, dietary assessment was not the main topic of the original study project, so patients may not have been sensitized to nutrition. The descriptive data show few differences between the original study population and the subgroup with FFQ data; thus, selection bias can largely be excluded as a source of error. ${ }^{29}$ Second, phytoestrogen data in- 
TABLE IV - CRUDE AND ADJUSTED ${ }^{1}$ ORS AND 95\% CIS FOR PREMENOPAUSAL BREAST CANCER RISK BY PHYTOESTROGEN INTAKE

\begin{tabular}{|c|c|c|c|c|c|c|c|c|c|}
\hline & \multicolumn{4}{|c|}{ Crude results } & \multicolumn{4}{|c|}{ Adjusted results } & \multirow{3}{*}{$p_{\text {trend }}$} \\
\hline & \multicolumn{4}{|c|}{ Quartiles } & \multicolumn{4}{|c|}{ Quartiles } & \\
\hline & $\mathrm{I}$ & II & III & IV & $\mathrm{I}$ & II & III & IV & \\
\hline Formononetin & & & & & & & & & 0.395 \\
\hline $\begin{array}{l}\text { OR } \\
\text { (CI) }\end{array}$ & 1 & $\begin{array}{c}1.27 \\
(0.83-1.93)\end{array}$ & $\begin{array}{c}1.70 \\
(1.13-2.56)\end{array}$ & $\begin{array}{c}1.33 \\
(0.87-2.03)\end{array}$ & 1 & $\begin{array}{c}1.32 \\
(0.85-2.04)\end{array}$ & $\begin{array}{c}1.65 \\
(1.07-2.54)\end{array}$ & $\begin{array}{c}1.14 \\
(0.72-1.82)\end{array}$ & \\
\hline Biochanin A & & & & & & & & & 0.747 \\
\hline $\begin{array}{l}\text { OR } \\
\text { (CI) }\end{array}$ & 1 & $\begin{array}{c}0.90 \\
(0.58-1.39)\end{array}$ & $\begin{array}{c}1.76 \\
(1.18-2.63)\end{array}$ & $\begin{array}{c}1.04 \\
(0.68-1.60)\end{array}$ & 1 & $\begin{array}{c}0.90 \\
(0.57-1.41)\end{array}$ & $\begin{array}{c}1.63 \\
(1.07-2.49)\end{array}$ & $\begin{array}{c}0.85 \\
(0.53-1.38)\end{array}$ & \\
\hline $\begin{array}{l}\text { Daidzein } \\
\text { OR } \\
\text { (CI) }\end{array}$ & 1 & $\begin{array}{c}0.74 \\
(0.50-1.10)\end{array}$ & $\begin{array}{c}0.83 \\
(0.56-1.25)\end{array}$ & $\begin{array}{c}0.82 \\
(0.55-1.22)\end{array}$ & 1 & $\begin{array}{c}0.62 \\
(0.41-0.94)\end{array}$ & $\begin{array}{c}0.72 \\
(0.47-1.09)\end{array}$ & $\begin{array}{c}0.62 \\
(0.40-0.95)\end{array}$ & 0.065 \\
\hline $\begin{array}{l}\text { Genistein } \\
\text { OR } \\
\text { (CI) }\end{array}$ & 1 & $\begin{array}{c}0.77 \\
(0.52-1.15)\end{array}$ & $\begin{array}{c}0.81 \\
(0.55-1.19)\end{array}$ & $\begin{array}{c}0.63 \\
(0.42-0.94)\end{array}$ & 1 & $\begin{array}{c}0.72 \\
(0.47-1.10)\end{array}$ & $\begin{array}{c}0.68 \\
(0.44-1.05)\end{array}$ & $\begin{array}{c}0.47 \\
(0.29-0.74)\end{array}$ & 0.002 \\
\hline $\begin{array}{l}\Sigma \text { Daidzein }+ \text { genistein } \\
\quad \text { OR } \\
\quad(\mathrm{CI})\end{array}$ & 1 & $\begin{array}{c}0.89 \\
(0.60-1.30)\end{array}$ & $\begin{array}{c}0.73 \\
(0.49-1.09)\end{array}$ & $\begin{array}{c}0.73 \\
(0.49-1.10)\end{array}$ & 1 & $\begin{array}{c}0.79 \\
(0.53-1.19)\end{array}$ & $\begin{array}{c}0.63 \\
(0.41-0.96)\end{array}$ & $\begin{array}{c}0.56 \\
(0.36-0.87)\end{array}$ & 0.005 \\
\hline $\begin{array}{l}\Sigma \text { Isoflavonoids } \\
\text { OR } \\
\quad \text { (CI) }\end{array}$ & 1 & $\begin{array}{c}1.16 \\
(0.78-1.73)\end{array}$ & $\begin{array}{c}0.82 \\
(0.54-1.25)\end{array}$ & $\begin{array}{c}1.16 \\
(0.78-1.73)\end{array}$ & 1 & $\begin{array}{c}1.03 \\
(0.68-1.56)\end{array}$ & $\begin{array}{c}0.71 \\
(0.46-1.10)\end{array}$ & $\begin{array}{c}0.85 \\
(0.54-1.33)\end{array}$ & 0.229 \\
\hline $\begin{array}{l}\text { Secoisolariciresinol } \\
\text { OR } \\
\text { (CI) }\end{array}$ & 1 & $\begin{array}{c}1.00 \\
(0.66-1.51)\end{array}$ & $\begin{array}{c}0.98 \\
(0.65-1.48)\end{array}$ & $\begin{array}{c}1.14 \\
(0.76-1.70)\end{array}$ & 1 & $\begin{array}{c}0.96 \\
(0.62-1.49)\end{array}$ & $\begin{array}{c}0.91 \\
(0.59-1.41)\end{array}$ & $\begin{array}{c}1.12 \\
(0.73-1.73)\end{array}$ & 0.648 \\
\hline $\begin{array}{l}\text { Matairesinol } \\
\text { OR } \\
\text { (CI) }\end{array}$ & 1 & $\begin{array}{c}0.91 \\
(0.61-1.36)\end{array}$ & $\begin{array}{c}0.89 \\
(0.60-1.32)\end{array}$ & $\begin{array}{c}0.83 \\
(0.55-1.24)\end{array}$ & 1 & $\begin{array}{c}0.80 \\
(0.52-1.22)\end{array}$ & $\begin{array}{c}0.72 \\
(0.47-1.11)\end{array}$ & $\begin{array}{c}0.58 \\
(0.37-0.94)\end{array}$ & 0.025 \\
\hline $\begin{array}{l}\Sigma \text { Lignans } \\
\text { OR } \\
\quad(\mathrm{CI})\end{array}$ & 1 & $\begin{array}{c}1.04 \\
(0.69-1.57)\end{array}$ & $\begin{array}{c}0.91 \\
(0.60-1.38)\end{array}$ & $\begin{array}{c}1.13 \\
(0.76-1.68)\end{array}$ & 1 & $\begin{array}{c}1.00 \\
(0.65-1.54)\end{array}$ & $\begin{array}{c}0.84 \\
(0.54-1.30)\end{array}$ & $\begin{array}{c}1.10 \\
(0.72-1.70)\end{array}$ & 0.837 \\
\hline $\begin{array}{l}\text { Coumestrol } \\
\text { OR } \\
\text { (CI) }\end{array}$ & 1 & $\begin{array}{c}1.05 \\
(0.69-1.58)\end{array}$ & $\begin{array}{c}1.22 \\
(0.82-1.82)\end{array}$ & $\begin{array}{c}1.08 \\
(0.72-1.64)\end{array}$ & 1 & $\begin{array}{c}1.05 \\
(0.68-1.61)\end{array}$ & $\begin{array}{c}1.16 \\
(0.76-1.77)\end{array}$ & $\begin{array}{c}0.92 \\
(0.59-1.44)\end{array}$ & 0.855 \\
\hline $\begin{array}{l}\Sigma \text { Phytoestrogens } \\
\text { OR } \\
\text { (CI) }\end{array}$ & 1 & $\begin{array}{c}0.91 \\
(0.61-1.35)\end{array}$ & $\begin{array}{c}0.91 \\
(0.61-1.37)\end{array}$ & $\begin{array}{c}0.94 \\
(0.63-1.40)\end{array}$ & 1 & $\begin{array}{c}0.87 \\
(0.57-1.33)\end{array}$ & $\begin{array}{c}0.80 \\
(0.52-1.24)\end{array}$ & $\begin{array}{c}0.83 \\
(0.53-1.24)\end{array}$ & 0.366 \\
\hline $\begin{array}{l}\text { Enterodiol } \\
\text { OR } \\
\text { (CI) }\end{array}$ & 1 & $\begin{array}{c}0.98 \\
(0.66-1.46)\end{array}$ & $\begin{array}{c}0.89 \\
(0.60-1.33)\end{array}$ & $\begin{array}{c}0.83 \\
(0.56-1.25)\end{array}$ & 1 & $\begin{array}{c}0.86 \\
(0.57-1.32)\end{array}$ & $\begin{array}{c}0.77 \\
(0.50-1.19)\end{array}$ & $\begin{array}{c}0.61 \\
(0.39-0.98)\end{array}$ & 0.034 \\
\hline $\begin{array}{l}\text { Enterolactone } \\
\text { OR } \\
\text { (CI) }\end{array}$ & 1 & $\begin{array}{c}1.13 \\
(0.76-1.68)\end{array}$ & $\begin{array}{c}0.91 \\
(0.61-1.36)\end{array}$ & $\begin{array}{c}0.86 \\
(0.57-1.29)\end{array}$ & 1 & $\begin{array}{c}1.04 \\
(0.68-1.57)\end{array}$ & $\begin{array}{c}0.72 \\
(0.46-1.12)\end{array}$ & $\begin{array}{c}0.57 \\
(0.35-0.92)\end{array}$ & 0.008 \\
\hline $\begin{array}{l}\Sigma \text { Intestinal lignan metabolites } \\
\text { OR } \\
\text { (CI) }\end{array}$ & 1 & $\begin{array}{c}0.98 \\
(0.66-1.46)\end{array}$ & $\begin{array}{c}0.89 \\
(0.60-1.33)\end{array}$ & $\begin{array}{c}0.83 \\
(0.56-1.25)\end{array}$ & 1 & $\begin{array}{c}0.86 \\
(0.57-1.32)\end{array}$ & $\begin{array}{c}0.77 \\
(0.50-1.19)\end{array}$ & $\begin{array}{c}0.61 \\
(0.39-0.98)\end{array}$ & 0.034 \\
\hline
\end{tabular}

${ }^{1}$ Adjusted for first-degree family history of breast cancer, number of births, duration of breast-feeding, energy intake, BMI, alcohol consumption and education.

TABLE V - ADJUSTED ${ }^{1}$ ORS AND 95\% CIS FOR PREMENOPAUSAL BREAST CANCER RISK BY COMBINATIONS OF LOW AND HIGH ${ }^{2}$ DIETARY INTAKE OF DAIDZEIN AND GENISTEIN AND OF ENTERODIOL AND ENTEROLACTONE

\begin{tabular}{|c|c|c|c|c|}
\hline \multirow{3}{*}{$\begin{array}{c}\sum \text { Daidzein }+ \\
\text { genistein } \\
\Sigma \text { Enterodiol }+ \\
\text { enterolactone }\end{array}$} & \multicolumn{4}{|c|}{ Combination } \\
\hline & Low & High & Low & High \\
\hline & Low & Low & High & High \\
\hline Cases/controls & $91 / 192$ & $50 / 131$ & $64 / 141$ & $73 / 202$ \\
\hline OR & 1 & 0.71 & 0.86 & 0.57 \\
\hline (CI) & & $(0.46-1.10)$ & $(0.54-1.25)$ & $(0.36-0.83)$ \\
\hline
\end{tabular}

${ }^{1}$ Adjusted for first-degree family history of breast cancer, number of births, duration of breast-feeding, energy intake, BMI, alcohol consumption and education. $-{ }^{2}$ Low levels refer to 1 st and 2 nd quartiles, and high levels refer to 3 rd and 4th quartiles.

cluded in the database and used for intake calculations may be incomplete for several reasons. In the case of isoflavonoids, the most important though unsolved question is the use of soy and soy components (e.g., soy protein) as food additives. ${ }^{56}$ The discussion of possible health effects of soy was not yet popular during the field period of the study. Thus, it can be assumed that soy-derived food additives used in food manufacturing before 1995 were used mainly for technologic reasons and pertain largely to soy protein preparations (with widely varying isoflavonoid concentrations).

Regarding the lignans secoisolariciresinol and matairesinol, the most important food sources were considered but there may be other foods not analyzed so far. Several other plant lignans (e.g., pinoresinol, syringaresinol, lariciresinol) have been identified as precursors of enterodiol and enterolactone, ${ }^{57}$ but their concentrations in different foods are not available. This probably explains why the food sources of secoisolariciresinol and matairesinol are distinctly different from those of mammalian lignans (Table III). The most critical point, however, may be the production of enterodiol and enterolactone from ingested lignans in the human intestine. The extent of lignan conversion in the gut depends largely on the quantity and composition of the gut microflora. ${ }^{18}$ Here, we used data from Thompson et al. ${ }^{41}$ based on incubating different foods with freshly gained human feces. It has been reported that plasma enterolactone concentrations are decreased for several months after antibiotic therapy. ${ }^{58}$ Additionally, gut transit time and fat content of the diet appear to modulate the availability of mammalian lignans. ${ }^{18,59}$ Therefore, when calculating the available amount of mammalian lignans in the present study, the reported high inter- and intraindividual differences in the 
TABLE VI - ADJUSTED ${ }^{1}$ ORS AND 95\% CIS FOR TOTAL DAIDZEIN AND GENISTEIN INTAKE AND PREMENOPAUSAL BREAST CANCER RISK BY ESTROGEN AND PROGESTERONE RECEPTOR STATUS OF THE TUMOR

\begin{tabular}{|c|c|c|c|c|c|c|c|c|c|c|}
\hline & \multicolumn{4}{|c|}{ Estrogen receptor-positive } & \multirow{3}{*}{$p_{\text {trend }}$} & \multicolumn{4}{|c|}{ Estrogen receptor-negative } & \multirow{3}{*}{$p_{\text {trend }}$} \\
\hline & \multicolumn{4}{|c|}{ Quartiles } & & \multicolumn{4}{|c|}{ Quartiles } & \\
\hline & I & II & III & IV & & $\mathrm{I}$ & II & III & IV & \\
\hline $\begin{array}{l}\text { Cases/controls } \\
\text { OR } \\
\text { (CI) }\end{array}$ & $\begin{array}{c}43 / 162 \\
1\end{array}$ & $\begin{array}{c}40 / 171 \\
0.72 \\
(0.43-1.22)\end{array}$ & $\begin{array}{c}30 / 168 \\
0.55 \\
(0.32-0.95)\end{array}$ & $\begin{array}{c}26 / 165 \\
0.43 \\
(0.24-0.78)\end{array}$ & 0.003 & $\begin{array}{c}20 / 162 \\
1\end{array}$ & $\begin{array}{c}20 / 171 \\
0.83 \\
(0.40-1.69)\end{array}$ & $\begin{array}{c}18 / 168 \\
0.71 \\
(0.34-1.49)\end{array}$ & $\begin{array}{c}25 / 165 \\
1.03 \\
(0.41-1.49)\end{array}$ & 0.983 \\
\hline & \multicolumn{4}{|c|}{ Progesterone receptor-positive } & \multicolumn{6}{|c|}{ Progesterone receptor-negative } \\
\hline $\begin{array}{l}\text { Cases/controls } \\
\text { OR } \\
\text { (CI) }\end{array}$ & $\begin{array}{c}38 / 162 \\
1\end{array}$ & $\begin{array}{c}36 / 171 \\
0.71 \\
(0.41-1.22)\end{array}$ & $\begin{array}{c}27 / 168 \\
0.54 \\
(0.30-0.97)\end{array}$ & $\begin{array}{c}21 / 165 \\
0.37 \\
(0.19-0.71)\end{array}$ & 0.002 & $\begin{array}{c}25 / 162 \\
1\end{array}$ & $\begin{array}{c}23 / 171 \\
0.79 \\
(0.41-1.52)\end{array}$ & $\begin{array}{c}20 / 168 \\
0.63 \\
(0.32-1.24)\end{array}$ & $\begin{array}{c}28 / 165 \\
0.90 \\
(0.47-1.72)\end{array}$ & 0.642 \\
\hline
\end{tabular}

${ }^{1}$ Adjusted for first-degree family history of breast cancer, number of births, duration of breast-feeding, energy intake, BMI, alcohol consumption and education.

production of mammalian lignans ${ }^{53,60}$ could not be taken into account. Isoflavonoids also undergo intestinal metabolism, and the question of bioavailability of dietary isoflavonoids and their metabolites may also be important for understanding their health effects. ${ }^{61,62}$ Equol is the intestinal isoflavonoid metabolite with the strongest estrogenic activity, but it is produced in only about one-third of Caucasian people, depending largely on the intestinal microflora. 63

Due to the difficulty in accounting for sources, metabolism and bioavailability of dietary lignans, it is not surprising that the association with breast cancer in our study was not the same for mammalian and plant lignans. Both approaches suffer from imprecision: the lignan intake data do not reflect the bioavailable fraction of lignan metabolites, and the enterodiol and enterolactone in vitro data used for calculation may be biased due to differences in the physiologic gut flora between subjects.

We previously reported from the same study population a significantly reduced risk of breast cancer associated with high consumption of vegetables. ${ }^{29}$ Since vegetables are sources of enterodiol and enterolactone, it cannot be excluded that the mammalian lignan effect reflects a more healthy diet rich in vegetables. Dietary intervention studies have shown that a diet low in animal products and fat and high in complex carbohydrates, fruits and vegetables increases enterolactone plasma concentrations and affects the hor- monal profile. ${ }^{64,65}$ This supports the view that a "healthy" diet provides more bioavailable mammalian lignans but does not exclude the possibility that mammalian lignans exert their own biologic effects in humans

In conclusion, our results give clear epidemiologic evidence for a protective role against premenopausal breast cancer of a diet high (albeit low compared to Asian populations) in daidzein, genistein or matairesinol as well as estimated mammalian lignans enterodiol and enterolactone. The association between isoflavonoid intake and breast cancer risk was found only for hormone receptorpositive tumors, while the effect of mammalian lignans was independent of receptor status. Whether phytoestrogens are the underlying causal agents of a favorable diet or a favorable gut microflora or both in relation to reduced breast cancer risk remains to be established.

\section{ACKNOWLEDGEMENTS}

We are grateful to all participants for their help and patience as well as to the many gynecologists and oncologists in the 38 clinics of the study regions for allowing us to contact their patients. We also thank Ms. U. Eilber for data coordination and management and Ms. D. Zoller for programming and calculating dietary intake data.

\section{REFERENCES}

1. Benassayag C, Perrot-Applanat M, Ferre F. Phytoestrogens as modulators of steroid action in target cells. J Chromatogr B Biomed Sci Appl 2002;777:233-48.

2. Adlercreutz H, Mazur W. Phyto-oestrogens and Western diseases Ann Med 1997;29:95-120.

3. Bingham SA, Atkinson C, Liggins J, Bluck L, Coward A. Phytooestrogens: where are we now? Br J Nutr 1998;79:393-406.

4. Messina MJ. Isoflavone intakes in Japanese were overestimated. Am J Clin Nutr 1995;62:645.

5. Messina MJ, Persky V, Stechell KDR, Barnes S. Soy intake and cancer risk-a review of the in vitro and in vivo data. Nutr Cancer 1994;21:113-31.

6. Setchell KD, Borriello SP, Hulme P, Kirk DN, Axelson M. Nonsteroidal estrogens of dietary origin: possible roles in hormone-dependent disease. Am J Clin Nutr 1984;40:569-78.

7. Endogenous Hormones and Breast Cancer Collaborative Group. Endogenous sex hormones and breast cancer in postmenopausal women: reanalysis of nine prospective studies. J Natl Cancer Inst 2002;94: 606-16.

8. Adlercreutz H. Western diet and Western diseases: some hormonal and biochemical mechanisms and associations. Scand J Clin Lab Invest 1990;50(Suppl):3-23

9. Lamartiniere CA, Cotroneo MS, Fritz WA, Wang J, Mentor-Marcel R, Elgavish A. Genistein chemoprevention: timing and mechanisms of action in murine mammary and prostate. J Nutr 2002;132:552S$8 \mathrm{~S}$.
10. Adlercreutz H. Phytoestrogens and breast cancer. J Steroid Biochem Mol Biol 2003; 1803:1-6.

11. Kurzer MS. Hormonal effects of soy in premenopausal women and men. J Nutr 2002;132:570S-3S.

12. Kirk CJ, Harris RM, Wood DM, Waring RH, Huges PJ. Do dietary phytoestrogens influence susceptibility to hormone-dependent cancer by disrupting the metabolism of endogenous oestrogens? Biochem Soc Trans 2001;29:209-16.

13. Peeters PHM, Keinen Boker L, van der Schouw YT, Grobbee DE. Phytoestrogens and breast cancer risk. Review of the epidemiologic evidence. Breast Cancer Res Treat 2003;77:171-83.

14. Mazur W. Phytoestrogen content in foods. Baillieres Clin Endocrinol Metab 1998;12:729-42.

15. Keinan Boker L, van der Shouw YT, de Kleijn MJJ, Jacques PF, Grobbee DE, Peeters PHM. Intake of dietary phytoestrogens by Dutch women. J Nutr 2002;132:1319-28

16. Horn-Ross PL, John EM, Lee M, Steward SL, Koo J, Sakoda LC, Shiau AC, Goldstein J, Davis P, Perez-Stable EJ. Phytoestrogen consumption and breast cancer risk in a multiethnic population. Am J Epidemiol 2001;154:434-41.

17. Horn-Ross PL, Hoggatt KJ, West DW, Krone MR, Stewart SL, Anton-Culver H, Bernstein L, Deapen D, Peel D, Pinder R, Reynolds $\mathrm{P}$, Ross RK, et al. Recent diet and breast cancer risk: the California Teachers Study (USA). Cancer Causes Control 2002;13:407-15.

18. Wang LQ. Mammalian phytoestrogens: enterodiol and enterolactone. J Chromatogr B Biomed Sci Appl 2002;777:289-309. 
19. Raffaelli B, Hoikkala A, Leppälä E, Wähälä K. Enterolignans. J Chromatogr B Biomed Sci Appl 2002;777:29-43.

20. Ingram D, Sanders K, Kolybaba M, Lopez D. Case-control study of phyto-oestrogens and breast cancer. Lancet 1997;350:990-4.

21. Pietinen P, Stumpf K, Männistö S, Kataja V, Uusitupa M, Adlercreutz $\mathrm{H}$. Serum enterolactone and risk of breast cancer: a case-control study in eastern Finland. Cancer Epidemiol Biomarkers Prev 2001;10:33944.

22. Dai Q, Franke AA, Jin F, Shu XO, Hebert JR, Custer LJ, Cheng J, Gao YT, Zheng W. Urinary excretion of phytoestrogens and risk of breast cancer among Chinese women in Shanghai. Cancer Epidemiol Biomarkers Prev 2002;11:815-21.

23. Den Tonkelaar I, Keinan-Boker L, Veer PV, Arts CJM, Adlercreutz $\mathrm{H}$, Thijssen JH, Peeters PH. Urinary phytoestrogens and postmenopausal breast cancer risk. Cancer Epidemiol Biomarkers Prev 2001; 10:223-8

24. Hulten K, Winkvist A, Lenner P, Johansson R, Adlercreutz H, Hallmans G. An incident case-referent study on plasma enterolactone and breast cancer risk. Eur J Nutr 2002;41:168-76.

25. Chang-Claude J, Eby N, Kiechle M, Bastert G, Becher H. Breastfeeding and breast cancer risk by age 50 among women in Germany. Cancer Causes Control 2000;11:687-95.

26. Kropp S, Becher H, Nieters A, Chang-Claude J. Low to moderate alcohol consumption and breast cancer risk by age 50 years among women in Germany. Am J Epidemiol 2001;154:624-34

27. Bohlscheid-Thomas S, Hoting I, Boeing H, Wahrendorf J. Reproducibility and relative validity of food group intake in a food frequency questionnaire developed for the German part of EPIC project. Int J Epidemiol 1997;26:S59-70.

28. Bohlscheid-Thomas S, Hoting I, Boeing H, Wahrendorf J. Reproducibility and relative validity of energy and macronutrient intake of a food frequency questionnaire developed for the German part of EPIC project. Int J Epidemiol 1997;26:S71-81

29. Hermann S, Linseisen J, Chang-Claude J. Nutrition and breast cancer risk by age 50: a population-based case-control study in Germany. Nutr Cancer 2002:44:23-34

30. Mazur W, Fotsis T, Wähälä K, Ojala S, Salakka A, Adlercreutz H. Isotope dilution gas chromatographic-mass spectrometric method for the determination of isoflavonoids, coumestrol, and lignans in food samples. Anal Biochem 1996;233:169-80.

31. Mazur W, Adlercreutz H. Natural and anthropogenic environmental oestrogens: the scientific basis for risk assessment. Naturally occurring oestrogens in food. Pure Appl Chem 1998;70:1759-76.

32. Mazur WM, Duke JA, Wähälä K, Rasku S, Adlercreutz H. Isoflavonoids and lignans in legumes: nutritional and health aspects in humans. J Nutr Biochem 1998;9:193-200.

33. Mazur WM, Wähälä K, Rasku S, Salakka A, Hase T, Adlercreutz H Lignan and isoflavonoid concentrations in tea and coffee. Br J Nutr 1998;79:37-45

34. Mazur WM, Uehara M, Wähälä K, Adlercreutz H. Phyto-oestrogen content of berries, and plasma concentrations and urinary excretion of enterolactone after a single-strawberry meal in human subjects. $\mathrm{Br} \mathrm{J}$ Nutr 2000;83:381-7.

35. Liggins J, Bluck LJ, Runswick S, Atkinson C, Coward WA, Bingham SA. Daidzein and genistein contents of vegetables. Br J Nutr 2000; 84:717-25.

36. Liggins J, Bluck LJC, Runswick S, Atkinson C, Coward WA, Bingham SA. Daidzein and genistein content of fruits and nuts. J Nutr Biochem 2000;11:326-31.

37. Liggins J, Mulligan A, Runswick S, Bingham SA. Daidzein and genistein content of cereals. Eur J Clin Nutr 2002;56:961-6.

38. Horn-Ross PL, Barnes S, Lee M, Coward L, Mandel EJ, Koo J, John EM, Smith M. Assessing phytoestrogen exposure in epidemiologic studies: development of a database (United States). Cancer Causes Control 2000;11:289-98.

39. Franke AA, Custer LJ, Cerna CM, Narala K. Rapid HPLC analysis of dietary phytoestrogens from legumes and from human urine. Proc Soc Exp Biol Med 1995;208:18-26.

40. Lapcik O, Hill M, Hampl R, Wähälä K, Adlercreutz H. Identification of isoflavonoids in beer. Steroids 1998;63:14-20.

41. Thompson LU, Robb P, Serraino M, Cheung F. Mammalian lignan production from various foods. Nutr Cancer 1991;16:43-52.

42. Kumar NB, Cantor A, Allen K, Riccardi D, Cox CE. The specific role of isoflavones on estrogen metabolism in premenopausal women. Cancer 2002;94:1166-74.
43. Haggans CJ, Hutchins AM, Olson BA, Thomas W, Martini MC, Slavin JL. Effect of flaxseed consumption on urinary estrogen metabolites in postmenopausal women. Nutr Cancer 1999;33:188-95.

44. Haggans CJ, Travelli EJ, Thomas W, Martini MC, Slavin JL. The effect of flaxseed and wheat bran consumption on urinary estrogen metabolites in premenopausal women. Cancer Epidemiol Biomarkers Prev 2000;9:719-25.

45. Xu X, Duncan AM, Wangen KE, Kurzer MS. Soy consumption alters endogenous estrogen metabolism in postmenopausal women. Cancer Epidemiol Biomarkers Prev 2000;9:781-6.

46. Murkies A, Dalais FS, Briganti EM, Burger HG, Healy DL, Wahlqvist ML, Davis SR. Phytoestrogens and breast cancer in postmenopausal women: a case control study. Menopause 2000;7:289-96.

47. Zheng W, Dai Q, Custer LJ, Shu XO, Wen WQ, Jin F, Franke AA. Urinary excretion of isoflavonoids and the risk of breast cancer. Cancer Epidemiol Biomarkers Prev 1999;8:35-40.

48. Yamamoto S, Sobue T, Kobayashi M, Sasaki S, Tsugane S, Japan Public Health Center-Based Prospective Study on Cancer Cardiovascular Diseases Group. Soy, isoflavones, and breast cancer risk in Japan. J Natl Cancer Inst. 2003;95:906-13.

49. Wu AH, Wan P, Hankin J, Tseng CC, Yu MC, Pike MC. Adolescent and adult soy intake and risk of breast cancer in Asian-Americans. Carcinogenesis 2002;23:1491-6.

50. Valsta LM, Kilkkinen A, Mazur W, Nurmi T, Lampi AM, Ovask ML, Korhonen T, Adlercreutz H, Pietinen P. Phyto-oestrogen database of foods and average intake in Finland. Br J Nutr 2003;89:S31-8.

51. De Kleijn MJJ, van der Schouw YT, Wilson PWF, Adlercreutz H, Mazur W, Grobbee DE, Jaques PF. Intake of dietary phytoestrogens is low in postmenopausal women in the United States: the Framingham Study. J Nutr 2001;131:1826-32.

52. Van Erp-Baart MAJ, Brants HAM, Kiely M, Mulligan A, Turrini A, Sermoneta C, Kilkkinen A, Valsta LM. Isoflavone intake in four different European countries: the VENUS approach. Br J Nutr 2003; 89:S25-30

53. Kilkkinen A, Valsta LM, Virtamo J, Stumpf K, Adlercreutz H, Pietinen P. Intake of lignans is associated with serum enterolactone concentration in Finnish men and women. J Nutr 2003;133:1830-3.

54. Arai Y, Uehara M, Sato Y. Comparison of isoflavones among dietary intake, plasma concentration and urinary excretion of phytoestrogen intake. J Epidemiol 2000;10:127-35

55. Brandstetter BR, Korfmann A, Kroke A, Becker N, Schulze MB, Boeing H. Dietary habits in the German EPIC cohorts: food group intake estimated with the food frequency questionnaire. Ann Nutr Metab 1999;43:246-57

56. Fletcher RJ. Food sources of phyto-oestrogens and their precursors in Europe. Br J Nutr 2003;89:S39-43

57. Heinonen S, Nurmi T, Liukkonen K, Poutanen K, Wähälä K, Deyama $\mathrm{T}$, Nishibe $\mathrm{S}$, Adlercreutz $\mathrm{H}$. In vitro metabolism of plant lignans: new precursors of mammalian lignans enterolactone and enterodiol. J Agric Food Chem 2001;49:3178-86.

58. Kilkkinen A, Pietinen P, Klaukka T, Virtamo J, Korhonen P, Adlercreutz $\mathrm{H}$. Use of oral antimicrobials decreases serum enterolactone concentration. Am J Epidemiol 2002;155:472-7.

59. Lampe JW. Isoflavonoid and lignan phytoestrogens as dietary biomarkers. J Nutr 2003;133:956S-64S.

60. Kilkkinen A, Stumpf K, Pietinen P, Valsta LM, Tapanainen H, Adlercreutz $\mathbf{H}$. Determinants of serum enterolactone concentration. Am J Clin Nutr 2001;73:1094-100.

61. Hendrich S. Bioavailability of isoflavones. J Chromatogr B Biomed Sci Appl 2002;777:203-10.

62. Setchell KDR, Brown NM, Desai P, Zimmer-Nechemias L, Wolfe BE, Brashear WT, Kirschner AS, Cassidy A, Heubi JE. Bioavailability of pure isoflavones in healthy humans and analysis of commercial soy isoflavone supplements. J Nutr 2001;131:1362S-75S

63. Setchell KD, Brown NM, Lydeking-Olesen E. The clinical importance of the metabolite equol - a clue to the effectiveness of soy and its isoflavones. J Nutr 2002;132:3577-84.

64. Stumpf K, Pietinen P, Puska P, Adlercreutz $\mathrm{H}$. Changes in serum enterolactone, genistein, and daidzein in a dietary intervention study in Finland. Cancer Epidemiol Biomarkers Prev 2000;9:1369-72.

65. Berrino F, Bellati C, Secreto G, Camerini E, Pala V, Panico S, Allegro G, Kaaks R. Reducing bioavailable sex hormones through a comprehensive changing diet: the Diet and Androgens (DIANA) randomized trial. Cancer Epidemiol Biomarkers Prev 2001;10:25-33. 